\title{
How Did We Get Here: Binding of Print Theses and Dissertations to Processing Electronic Theses and Dissertations?
}

\begin{abstract}
In today's economic climate, many academic libraries are faced with smaller budgets and rising costs of materials. Electronic databases and journals are growing in most libraries, while print materials are decreasing. A shift in the change from print to electronic collections has impacted routine serials workflows. This article examines the change from print to electronic resources, the impact of technology on traditional technical services tasks and the serials staff workflow transition from print to electronic theses and dissertations dissemination at F.D. Bluford Library at North Carolina Agricultural and Technical State University.
\end{abstract}

The predicted shift from print to majority electronic resources is now a reality for academic libraries. This shift, prompted by budget reductions and technology, has caused libraries to reexamine the roles and workflows of staff responsible for the processing of print resources. The reduction of traditional serials workflow tasks coincided with the decision of F.D. Bluford Library at North Carolina Agricultural and Technical State University and the Graduate School to cease binding of print theses and dissertations. The serials staff discontinued print processing of theses and dissertations and began processing electronic versions in the university institutional repository using ContentDM information management software.

\section{Literature Review}

The words "serials crisis" according to Panitch \& Michalak, became a standard phrase used for the uncontrolled cost of numerous scholarly journals. ${ }^{1}$ Dougherty states that the serials crisis did not really start until 1984 , when librarians began to observe that subscription costs of designated journals were rising at extraordinary rates. ${ }^{2} \mathrm{He}$ credits this circumstance to the results of publishers placing high value on scientific and technical journals as if they were economic properties. In 1985 , for example, the library's annual subscription rate for the Journal of Comparative Neurology was $\$ 1,920$, with the cost growing in the year 2000 to $\$ 15,000$ dollars. Commercial publishers compounded journal prices at unexpected rates and gained profits that far exceeded what should have been considered reasonable for the product. ${ }^{2}$ Dougherty states that these decisions announced the end of scholarly publishing, as it had been in existence since the conclusion of World War II, and escorted in the introduction to the digital age. Therefore as a result of budget reductions and inflated print journal pricing, the decline in print serial subscriptions began, resulting in an increase of electronic resources in academic libraries. Library associations and publishers' surveys began to collect and examine data to analyze the change. ${ }^{3}$

In 2002 the Association of Research Libraries survey reported electronic resource purchases grew $400 \%$ between $1994 / 95$ and 2001/02. ${ }^{4}$ EBSCO Library and Publishers Communication Group surveys in February 2010 and 2011 showed over 80 percent of the librarian participants concluded there would be a shift from print plus online to online only subscriptions in an effort to reach budget goals. The Publishers Communication Group survey showed that large academic libraries allotted approximately $70 \%$ of their collection budgets to electronic resources in 2012..$^{5}$ Academic libraries that once purchased traditional print materials have shifted to building electronic collections, an alternative which is preferred by many users.

Many libraries have experienced a significant decrease in claims, checkins, and bindings since electronic resources have increased in libraries. In a 2009 North American Serials Interest Group (NASIG) program on serials workflow, discussions disclosed parallel concerns of staff workflow involving managing less print and more electronic serials . ${ }^{6}$ Most attendees concluded that reduction of traditional routine tasks of staff such as binding, check-in and claiming were taking place at their institutions. As a result of this workflow program dialogue, the program presenter in 2010 circulated a survey using the SERIALST discussion list, to gather additional information on what changes the shift from print to electronic serials had on positions and staff at other libraries. Sixtysix participants responded to the survey from various types of academic 
libraries, with the survey request that only administrators or librarians that had eliminated or greatly decreased print serials tasks reply.

The survey showed the task most frequently reduced was serials binding, with 31 percent of the respondents specifying elimination or a tremendous decline, while claiming accounted for 26 percent and 22 percent for check-in reductions. The libraries noted that the serials task affected most was that of binding (71\%). The libraries also reported 87 percent of the serial areas had large task reductions, as compared to total elimination which amounted to 13 percent. The survey clearly showed the decline on serials staff print workflows since the increase of electronic resources in academic libraries. With the influx of technology-driven collections, serials staff traditional workflows began to decline and technical service departments began to support scholarly research dissemination in non-traditional ways. ${ }^{6}$

\section{F.D.Bluford Library}

F. D. Bluford Library is committed to being a trusted partner of North Carolina Agricultural and Technical State University, and upholding the mission of interdisciplinary research, discovery, engagement, and operational excellence. The thirty-eight member staff offers services that support the university's mission for the physical and virtual environments. The library as a place is arranged to build collaboration, independent research, and study. Information services incorporate classes and workshops to enhance critical thinking and information literacy skills. The library offers access to multiple information resources in a variety of formats including print, audiovisual, and electronic. This substantial collection includes over 700,000 volumes of print and audiovisuals; 150,000 electronic books; and 300 databases. Over the next five years, the library anticipates the electronic and digital collections to grow considerably. Following the trends of many libraries, F. D. Bluford is transitioning from a collection of duplicate formats to electronic only. The library continues to partner in consortium relationships to leverage the cost and expand access to electronic resources. Additionally, cancellation. Currently, F.D. Bluford Library has 353 print serial subscriptions.

During the time of print cancellations, the university's School of Graduate Studies and the library were exploring the possibility of electronic theses and dissertations. Decisions made by the two entities would further impact the workflow of an already

\section{6 Many libraries have experienced a significant decrease in the numbers of claims, check-ins, and binding workflow with electronic resources increasing in libraries. 9}

digital initiatives have increased the number of digital collections available. The library has digitized photographs, university newspapers, and yearbooks while still identifying other archival and university materials to digitize. The institutional repository hosts the intellectual property of the university, including faculty publications, presentations, theses, and dissertations.

\section{Background}

During the 2009 fiscal year at F.D. Bluford Library, print journals were greatly affected due to budget shortages. To address the shortage, 968 print serial subscriptions were cancelled for the 2009/2010 fiscal year budget to reallocate to new electronic resources. As budget shortages continued, the library had to identify more reductions. In 2011, an E-Resource Taskforce committee was charged to examine, assess, and cancel duplicate print/electronic resources, along with sparsely-used titles, to reduce budget expenditures by $40 \%$ for the $2011 / 2012$ fiscal year. The work of this committee concluded with recommended cuts of 142 print serials and 66 print + online subscriptions. In 2013 the committee specified 25 additional print serials and 12 print + online subscriptions for changing serials department. With fewer print materials to process, serials staff would shift part of their workflow to processing electronic theses and dissertations.

\section{The Transition}

In 2012, F.D. Bluford Library and the School of Graduate Studies met to discuss transitioning from submission of print theses and dissertations to electronic submission of them to the library. There were several meetings between both parties to discuss and choose the information management content software and the roles of each department. Both agreed that UMI/ ProQuest would be used for submission of electronic versions of theses and dissertations for graduate students. Both also agreed the library would no longer receive print copies, but receive only one compact disc copy of the items to be added to the University Institutional Repository. The Graduate School would be responsible for all other phases of the transition, including offering multiple workshops to introduce the students to the new electronic thesis and dissertation (ETD) process; work with the university's information technology department to construct a university 
guidelines website; and format the outof-the-box ProQuest ETD Administrator website for North Carolina A\&T State University.

In the 2013 spring semester, graduate students were required to electronically submit theses and dissertations using UMI/ProQuest software, and also submit one compact disc copy (pdf format) to the Graduate School to forward to the library for submission into the University Institutional Repository, using ContentDM as the digital management software.

The library would fulfill its mission to support and advance academic scholarship and research globally. The library would also reduce the bindery budget expenditures, and shift serials staff workflow from a decreasing print workflow to a growing electronic environment by processing and providing electronic access to theses and dissertations.

\section{Serials Staff}

The Serials staff consists of a Head/ Serials librarian and two dedicated library technicians. The continuous goal of the Serials Department is to process and provide access to serial materials through cataloging, updating holding information, binding print journals, books, theses, dissertations, and checking-in newspapers and microforms. Database clean-up, labeling, processing received mail and claiming late titles are also responsibilities.

\section{Print process}

Preparing and processing print copies of theses and dissertations for delivery to the bindery was one of the staples of the serials department staff. Approximately 470 print theses and dissertations were processed on an annual basis. The print processing of theses and dissertations was a tedious process. The serials staff would receive 4 printed unbound copies of loose leaf pages for each thesis or dissertation, submitted by a graduate student to prepare for the bindery. As a part of the process, the staff would review each title page, signature page and abstract page, and order of page numbers for errors, along with making sure the copies were printed on $100 \%$ cotton acid-free paper, in an effort to preserve this scholarly research.

After the review, the staff input pertinent information into a web environment software, using the ABLE binding system, and submitted the item report electronically to the bindery company. The items were picked up on a weekly basis by the bindery and returned the next week to the library. Once the bound copies were returned, the serials staff unpacked the bound books, checked the spine and cover for spelling and call number errors, as well as correct colored book coverings, designating thesis or dissertation. The books were stamped and stripped. Afterwards the newly bound theses and dissertations were distributed with one copy sent to cataloging, and three copies to the Graduate School for the student, respective academic school department and advisor. The print process was time consuming, as attention to detail played an important part in this workflow.

The print processing of these items was also physically demanding. Folders and boxes of theses and dissertations were delivered from the Graduate School to the serials department. The staff was responsible for removing the items from the folders/boxes to count and make sure the correct number of student copies had been received. The number received was too great to sit on a staff member's desk. The staff would place them on a work truck and reach back and forth to retrieve the often heavy print copies of the theses and dissertations. The staff was also responsible for packing and unpacking the items that were sent and received from the bindery. This often included bending, stooping, and picking up of several heavy boxes, to be placed in the library's receiving area, for bindery pick-up, and when items were returned for processing.

\section{Electronic Submission process}

Processing of electronic theses and dissertations was a new workflow for the serials staff. Since the 1940s, print theses and dissertations were processed and sent to the bindery. This workflow no longer existed and staff would learn a new way of providing electronic access to this scholarly information.

The library uses web-accessible ContentDM digital management software as the platform for the University Institutional Repository. From the Graduate School, the serials staff receives a list with the students' names, semester and year of graduation, along with one compact disc of the electronic version of the thesis or dissertation in pdf form. The serials staff then compares the list of names to those labeled names on each compact disc to verify that all copies are received.

The staff saves the pdf copy on the hard drive in the folder named Graduates theses and dissertations. The staff $\log$ into ContentDM with provided username and password, creates a new item, uploads the PDF format of the thesis or dissertation and university thumbnail graphic, adds Dublin core metadata, Library of Congress subject headings and approves or saves the item. The items can be reviewed and edited on the approval screen. Once the item is reviewed and ready to be published, the index tab is opened and staff click Index Now to submit theses and dissertations. The electronic theses and dissertations are immediately available globally. 


\section{Lessons Learned}

The electronic processing of theses and dissertations is a straightforward process. ContentDM is a very user friendly information management software. It offers an intuitive interface and navigational layout. It is a webbased application as is the Able bindery software staff used when these items were processed in print; therefore, the staff are familiar with working in a web environment. elements: title, subject, description, creator, publisher, date, type, format, language, major professor, academic department and degree. With the print theses and dissertations, the bound items were forwarded by staff to the cataloging department for descriptive information for use in creating MARC records for the library's online catalog. The serials staff now adds descriptive language of the Dublin core metadata elements to these items for discovery

\section{The serials staff is transitioning from the routine labor}

of physical processing of items to electronic processing... allowing dissemination of scholarly research of theses and dissertations within days, instead of weeks to users. 9

The interface of ContentDM has similarities to the library's integrated library system serials module. Both use tabs to navigate back and forth to different screens for the user to add pertinent information. Therefore familiarity of the tab features made it easier for staff to navigate the software.

The saving of the pdfs on the library's shared drive, and locating the correct file to upload these items, required the most time for staff to learn, as there are multiple steps and folders to open before locating the graduate thesis and dissertation folder. Uploading a thumbnail graphic to market the electronic versions in the institutional repository was also a step staff frequently missed when staff input item information.

The processing of electronic resources introduced staff to Dublin Core metadata schema. It includes a group of vocabulary terms (elements) that can be used to describe various resources, including web resources. The Dublin Core metadata terms the staff uses to describe the electronic versions of the university's theses and dissertations in ContentDM consist of 12

in the institutional repository.

The subject area in ContentDM software for added items can include Library of Congress subject headings (LCSH) or keywords for discovery in the institutional repository. The library initially required only LCSH controlled vocabulary terms to be added to the items for access points for users. This decision presented a backlog of electronic theses and dissertations, waiting for weeks to be electronically published in the university institutional repository. After further discussions with the Head of Cataloging and Technical Services, the decision was made to use keywords and publish immediately to the institutional repository after adding information in ContentDM.

Currently, the staff uses the student's major departments as the keywords for an access point for discovery in the university institutional repository. For example, if the thesis comes from the computer and electrical engineering department, computer and electrical engineering are used for the key words.

Having a dedicated day each week to only add LCSH to the electronic theses and dissertations and requesting that students submit other keywords for discovery of their scholarly research are options that are being discussed. The Graduate School currently does not require students to add subject/ topic keywords in their formal submission of theses and dissertations. The library recently communicated with the Coordinator of Graduate Writing Services, and shared it would be useful for students to include keywords for discovery purposes of their electronic theses and dissertations. The coordinator stated they did not have a consistent standard for including keywords. $\mathrm{He}$ agreed it was a useful tool, and would update the electronic theses and dissertations formal requirements to include keywords on the abstract page.

\section{Staff time}

The staff spent an average of 15 to 20 minutes reviewing and processing each print thesis and/or dissertation to be sent to the bindery. The staff also had to spend an additional time of 10 to 20 minutes per item, unpacking, reviewing and processing the returned bound volumes from the bindery. The total average time staff spent processing each print thesis/dissertation from loose leaf materials to a bound volume for the library was approximately 25 to 40 minutes. In comparison, the staff averages 10 to 15 minutes uploading the pdf, adding metadata and keywords to submit each electronic thesis or dissertation into ContentDM, cutting the total processing time of these items by 25 minutes.

The time saved from the duties of processing print theses and dissertations has allowed staff additional time to perform needed database clean-up of serial records, update holding statements of canceled print subscriptions and participate in the inventorying of the library's collection. 


\section{Conclusion}

In conclusion, budget shortages and the shift to electronic collections have affected serials staff workflow. The traditional tasks of claiming, check-ins and binding have decreased in these departments. The serials staff is transitioning from the routine labor of physical processing of items to electronic processing. Technology has ushered in these new workflow changes, allowing dissemination of scholarly research of theses and dissertations within days instead of weeks.

The serials staff workflow change has allowed staff to apply previous skills and learn new skills using ContentDM information management software. Familiarity with other similar web interfaces and environments processing print items made the transition easier than expected. Also learning a new descriptive language, Dublin Core metadata, will serve the serials staff well, as the library will continue to collaborate and participate in other digital initiatives with university partners.

\section{References}

${ }^{1}$ Judith M. Panitch and Sarah Michalak, "The serials crisis: a whitepaper for the UNC-Chapel Hill Scholarly Communication Convocation," accessed October 22, 2014, http://www.unc.edu/scholcomdig/whitepapers/ panitch-michalak.html

${ }^{2}$ Richard M. Dougherty, "Reflections on 25 years of JAL and academic libraries," \ournal of Academic Librarianship, 25, no. 1 (1999): 3-8.

${ }^{3}$ Ray English and Larry L. Hardesty, "Create Change: Shaping the Future of Scholarly Journal Publishing." College and Research Libraries News 61, no. 6 (June 2000), 515-518.

${ }^{4}$ Mary M. Case, "A Snapshot in Time: ARL Libraries and Electronic Journal Resources," ARL Bimonthly Report, accessed November 5, 2014, http://www.arl.org/storage/documents/publications/arl-br-235.pdf.

${ }_{5}^{5}$ Publishers Communication Group. 2013. Library Budget Predictions for 2013. Boston, MA: Publishers Communication Group.

${ }^{6}$ Sarah Glasser, S., and Michael A. Arthur, "When Jobs Disappear: The Staffing Implications of the Elimination of Print Serials Management Tasks," Serials Librarian 60, no. 1-4 (2011): 109-113.

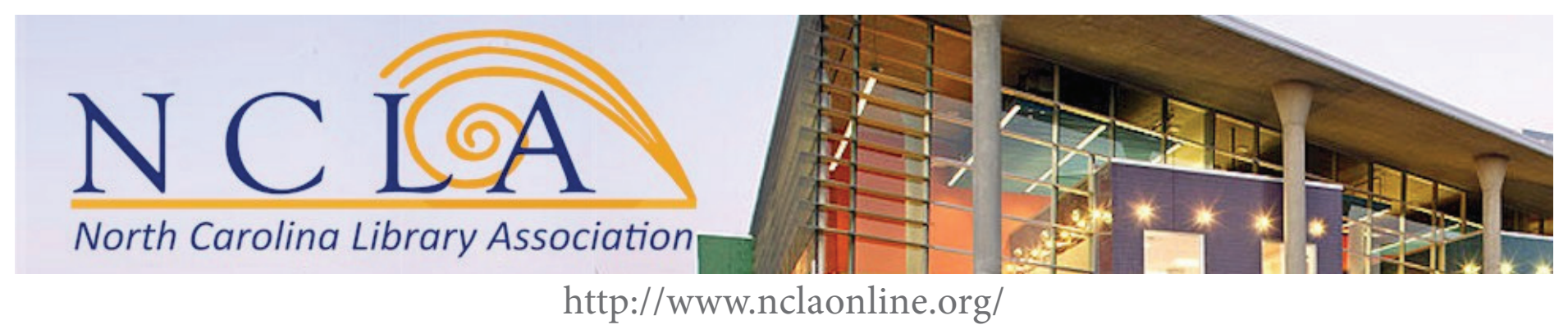

